\title{
THERMOPHYSICAL PROPERTIES OF JACKFRUIT PULP AFFECTED BY CHANGES IN MOISTURE CONTENT AND TEMPERATURE
}

\section{MICHELLE A. SOUZA ${ }^{1}$, RENATA C.F. BONOMO ${ }^{2,4}$, RAFAEL C.I. FONTAN ${ }^{2}$, LUIS ANTONIO MINIM ${ }^{3}$ and JANE SÉLIA DOS REIS COIMBRA ${ }^{3}$}

\author{
${ }^{1}$ Centro Federal de Educação Tecnológica da Bahia \\ Porto Seguro, BA, Brazil \\ ${ }^{2}$ Universidade Estadual do Sudoeste da Bahia \\ Department of Rural and Animal Technology \\ Engineering Process Laboratory \\ Praça Primavera \\ Itapetinga, BA, Brazil \\ ${ }^{3}$ Universidade Federal de Viçosa \\ Department of Food Technology \\ Av. P. H. Rolfs, $s / n$, Campus Universitário \\ Viçosa, MG, Brazil
}

Accepted for Publication March 20, 2009

\begin{abstract}
Thermophysical properties of jackfruit (Artocarpus heterophyllus L.) pulp affected by temperature and moisture content were analyzed. Density $(\rho)$, heat capacity $\left(\mathrm{c}_{p}\right)$ and thermal diffusivity $(\alpha)$ were experimentally determined at moisture content between $65 \% \mathrm{~m} / \mathrm{m}$ and $95 \% \mathrm{~m} / \mathrm{m}$, and temperatures between 5 and $85 \mathrm{C}$. Then, thermal conductivity was calculated from experimental results of thermal diffusivity, specific heat and density. The empirical models for each property as a function of moisture content and temperature were obtained $\left(\mathrm{R}^{2} \geq 0.90\right)$. Estimated equations were fitted to the experimental data for density and specific heat, and the accuracy of those equations was checked.
\end{abstract}

\section{PRACTICAL APPLICATIONS}

The design of juice concentrate plants needs thermophysical parameters. Information about tropical and exotic fruits, such as jackfruit, is insufficient,

${ }^{4}$ Corresponding author. TEL: +55-77-3261-8659; FAX: +55-77-3261-8601; EMAIL: bonomorcf@ pq.cnpq.br 
and much specific information is still unknown. The knowledge of how temperature and moisture content affect properties such as density, specific heat, thermal diffusivity and thermal conductivity will enable the development, adaptation and optimization of more efficient specific equipment for processing jackfruit.

\section{INTRODUCTION}

Jackfruit belongs to Moracea family, and it is widely distributed among countries such as Thailand, Indonesia, Philippines and Malaysia. In Brazil, there is a large area occupied by the fruit from north to southeastern regions of the country, especially in humid regions of tropical forests. It is a fruit rich in carbohydrates, considered energetic. In its composition, it contains calcium, phosphorus, iron and vitamins of B complex, especially B2 vitamin (riboflavin) and B5 vitamin (niacin) (Jagadeesh et al. 2007). Vitamin content and some volatile compounds contribute to its very peculiar flavor (Rahman et al. 1999).

Adequate manufacturing process, proper design of concentrate plants and appropriate evaluation of their performance will facilitate optimization of quality parameters of the concentrate juices. The plant efficiency is obtained from physical properties of both the raw material and the products (Zuritz et al. 2005).

According to Coimbra et al. (2006), density $(\rho)$, heat capacity $\left(c_{\mathrm{p}}\right)$, thermal conductivity $(k)$ and thermal diffusivity $(\alpha)$ are the major thermophysical properties required for evaluating, designing and modeling heat transfer processes, such as refrigeration, freezing, heating or drying.

Tansakul and Chaisawang (2006) recommended that empirical models of thermal properties developed for each specific food material should give a more accurate prediction. However, several researches have evaluated the existence of models for similar products in order to check their applicability to predict their thermophysical properties because of the importance of using valid equations resulting in time, money and material savings (Becker and Fricke 1999; Muniz et al. 2006).

Studies of thermophysical properties have been reported for many juices (Aguado and Ibarz 1988; Ramos and Ibarz 1998; Cepeda and Villarán 1999; Zainal et al. 2000; Azoubel et al. 2005; Shamsudin et al. 2005; Zuritz et al. 2005; Magerramov et al. 2007). However, the majority of available fruit data are focused on subtropical ones, leaving a lack of published information regarding thermal properties of tropical fruits and their products, such as juices and pulps (Azoubel et al. 2005).

The objectives of this work were to: (1) determine the physicochemical characteristics of jackfruit pulp such as proximate analysis, $\mathrm{pH}$, titratable 
acidity and soluble solids; (2) investigate the effects of temperature (5-85C) and moisture content $(65-95 \% \mathrm{~m} / \mathrm{m})$ on thermophysical properties of jackfruit pulp, providing experimental data about an unexplored tropical fruit pulp; and (3) propose simpler models in order to predict its properties.

\section{MATERIALS AND METHODS}

\section{Sample Preparation}

Jackfruit pulps of seven different moisture content values were prepared from fruits at medium maturity. The initial moisture content values were equal to $65,70,75,80,85,90,95 \%(\mathrm{~m} / \mathrm{m})$ wet basis. Jackfruits were first washed using tap water, cut, and their pulp was manually removed, homogenized mechanically and stored under $-10 \mathrm{C}$. The moisture content of the integral pulp was $75 \% \mathrm{~m} / \mathrm{m}$. The $80,85,90,95 \%(\mathrm{~m} / \mathrm{m})$ pulps were made by reconstituting the original pulp using distilled water. The concentration of jackfruit pulp was carried out in a rotary evaporator, in which the evaporation chamber under vacuum conditions was rotating at a constant speed in water bath at $60 \mathrm{C}$. The solutions were concentrated until reaching moisture content equal to 65 and $70 \%(\mathrm{~m} / \mathrm{m})$.

\section{Proximate, Physicochemical and Statistical Analysis}

Integral jackfruit pulp was used in the proximate analysis. The analysis included protein, fat, ash, moisture and fiber. Water content and fat content were measured using the oven method and the Soxhlet method, respectively. Determination of fiber in jackfruit pulp was based on the method used by AOAC (1996). The Kjeldahl method was used for protein determination. For ash content, the sample was first dried in an oven at $100 \mathrm{C}$ before being transferred to a muffle furnace at $550 \mathrm{C}$ until acquiring a white or light gray ash. The samples of jackfruit pulp were characterized by the following physicochemical determinations: soluble solids concentration (ATAGO refractometer, Atago, Bellevue, WA) and pH (QUIMIS pH meter, São Paulo, Brazil). The carbohydrate determination was made by difference. These procedures were repeated three times.

Statistical analyses were performed using SAEG v.8.1 statistical software (Ribeiro Júnior 2001). The suitability of models was evaluated by values of determination coefficient $\left(R^{2}\right)$, level of significance $(p)$ and residual analysis.

\section{Thermophysical Properties}

Density. Density of jackfruit pulp at different temperatures (5-85C) and concentrations $(65-95 \% \mathrm{~m} / \mathrm{m})$ was determined in triplicate by weighing in an 
analytical balance, accuracy of $\pm 0.0001 \mathrm{~g}$ (model AG200, Gehaka, São Paulo, Brazil), the pulp inside a standard volumetric pycnometer (Constenla et al. 1989). Sample temperature varied by thermostatic bath stabilization, accuracy of $\pm 0.01 \mathrm{C}$ (model Q214S2, QUIMIS). The pycnometer of $25 \mathrm{~mL}$ was previously calibrated with distilled water at each temperature. The density of jackfruit pulp was calculated using Eq. (1).

$$
\rho=\rho_{w} \cdot \frac{\left(m_{s}-m_{v}\right)}{\left(m_{w}-m_{v}\right)}
$$

Specific Heat (Cp). In order to determine the specific heat of jackfruit pulp, a method of mixtures with the analyses was conducted six times. This method, despite existent errors $(\sim 10 \%)$, is very simple and has been extensively used to determine the specific heat of foodstuffs (Hwang and Hayakawa 1979; Rapusas and Driscoll 1995; Omobuwajo et al. 2000; Oyelade et al. 2005; Muniz et al. 2006; Razavi and Taghizadeh 2007; Fontan et al., in press).

The used calorimeter consists of a thermal glass bottle of double walls isolated with a $20 \mathrm{~cm}$ thick of polystyrene layer and a thermocouple of copper-constantan (model Penta, Full Gauge, São Paulo, Brazil; accuracy of $\pm 0.1 \mathrm{C}$ ) inserted in it.

To determine the specific heat of the samples, first was determined heat capacity of the calorimeter. The calorimeter was half filled with cold distilled water (12C) and left at rest until it reached thermal equilibrium. Then, the volume of the calorimeter was completed with warm distilled water (45C), left at rest until it reached thermal equilibrium. This procedure was conducted 10 times. Then, heat capacity was calculated as proposed by Eq. (2a), turning the specific heat of the samples possible to determine (Eq. 2b).

The calibrated calorimeter was filled with cold water (12C) and left until it reached thermal equilibrium. Then, a sample mass (around $45 \mathrm{~g}$ ) at $45 \mathrm{C}$ in a polyethylene bag was inserted in the calorimeter, and left at rest until it reached thermal equilibrium. The specific heat of the sample was determined as proposed by Eq. (2b) (Fontan et al., in press).

$$
\begin{gathered}
C_{c a l}=\frac{m_{h} \cdot c_{w} \cdot\left(T_{h}-T_{e q}\right)-m_{c} \cdot c_{w} \cdot\left(T_{e q}-T_{c}\right)}{\left(T_{e q}-T_{c}\right)} \\
c_{p}=\frac{\left(c_{w} \cdot m_{w}+C_{c a l}\right)\left(T_{e q}-T_{0}\right)}{m_{s}\left(T_{s}-T_{e q}\right)}
\end{gathered}
$$


Thermal Diffusivity. For determining thermal diffusivity, the adapted method of Dickerson (1965) was applied using a metallic capsule of stainless steel ( $3.8 \mathrm{~cm}$ in diameter, $25.5 \mathrm{~cm}$ in height and $1.0 \mathrm{~mm}$ in thickness) with two copper-constantan thermocouples, one in the external surface of the capsule and the at the center; and a cinematic bath, accuracy of 0.1C (model MA185, Marconi, São Paulo, Brazil). In order to calculate the thermal diffusivity of the sample, the following equation was used:

$$
\alpha=\frac{A \cdot R^{2}}{4 \cdot\left(T_{E X T}-T_{I N T}\right)}
$$

Thermal Conductivity. Thermal conductivity values to jackfruit pulp under studied temperatures were obtained using correlation among density, thermal diffusivity and specific heat (Eq. 4). This correlation is very common to determine thermal diffusivity values once thermal conductivity values are experimentally obtained (Szczesniak 1983; Telis-Romero et al. 1998; Belibagli et al. 2003; Tansakul and Chaisawang 2006; Marcotte et al. 2008). Because thermal diffusivity values were determined by adopting an experimental method in this study, the correlation was used to calculate thermal conductivity values.

$$
k=\alpha \cdot \rho \cdot c_{p}
$$

\section{Experimental Design}

In order to study the effect of temperature and moisture content on thermophysical properties of jackfruit pulp, a series of experiments was set up. To determine the effect on density, it was conducted a $9 \times 7$ factorial scheme experiment, in which nine levels were given to temperature $(5,15,25,35,45$, $55,6575$ and $85 \mathrm{C})$ and seven levels to moisture content $(65,70,7580,85,90$, $95 \%$, all $\mathrm{m} / \mathrm{m}$ in humid base) set up in an entirely casual design (ECD).

A $9 \times 5$ factorial scheme experiment was set up for experimental determination of thermal diffusivity, with the same temperatures mentioned and five levels given to moisture content $(70,80,85,90,95 \%$, in humid basis) at the ECD. Density and thermal diffusivity determination analyses were realized in three repetitions with triplicate each one.

To the specific heat study, seven levels for moisture content were analyzed (the same levels used to density) at the ECD, with three repetitions in six replicates each one.

The obtained results were analyzed by analysis of variance with a 5\% of probability by Fisher test and regression analysis by the parameter significance 
(Student's test, $P<0.05)$, residual analysis and determination coefficient $\left(R^{2}\right)$. All statistical analyses were conducted in the statistical software SAEG, v.8.1 (Ribeiro Júnior 2001).

\section{RESULTS AND DISCUSSION}

\section{Proximate and Physicochemical Analysis}

Table 1 shows experimental values for proximate and physicochemical analysis of jackfruit pulp. It can be observed a large value of carbohydrate and soluble solids. It is clear that the solid content of the jackfruit pulp consists of carbohydrates predominantly. The pulp also presents high ash content, being a potential source of energy and minerals to human nutrition. The values of $\mathrm{pH}$, soluble solids and titrable acidity shown in Table 1 are in good agreement with those obtained by Rahman et al. (1999) and Jagadeesh et al. (2007).

\section{Thermophysical Properties}

Density. As indicated, experimental density values were correlated with temperature $(T)$ and moisture content $\left(X_{\mathrm{w}}\right)$ by multiple linear regression. The results of statistical analyses showed that the second-order polynomial equation is the best to express density as a function of temperature and moisture content (Eq. 5).

$$
P=1,843.680-15.810 X_{\mathrm{w}}+0.077 X_{\mathrm{w}}^{2}-0.09 T-0.010 T^{2} \quad R^{2}=0.97
$$

The density of jackfruit pulp decreased as temperature and moisture content increased (Fig. 1). Temperature changes may influence density

TABLE 1.

RESULTS OF APROXIMATE AND PHYSICOCHEMICAL ANALYSIS OF JACKFRUIT PULP

\begin{tabular}{lr}
\hline $\mathrm{pH}$ & $4.82 \pm 0.00$ \\
Soluble solids $\left({ }^{\circ}\right.$ Brix) & $23.00 \pm 0.01$ \\
Titrable acidity (\%, citric acid) & $1.04 \pm 0.01$ \\
Moisture content (\%) & $75.39 \pm 0.08$ \\
Carbohydrate (\%) & $19.63 \pm 0.15$ \\
Protein (\%) & $0.77 \pm 0.08$ \\
Fat $(\%)$ & $0.30 \pm 0.01$ \\
Fiber $(\%)$ & $0.20 \pm 0.02$ \\
Ash $(\%)$ & $3.71 \pm 0.58$ \\
\hline
\end{tabular}




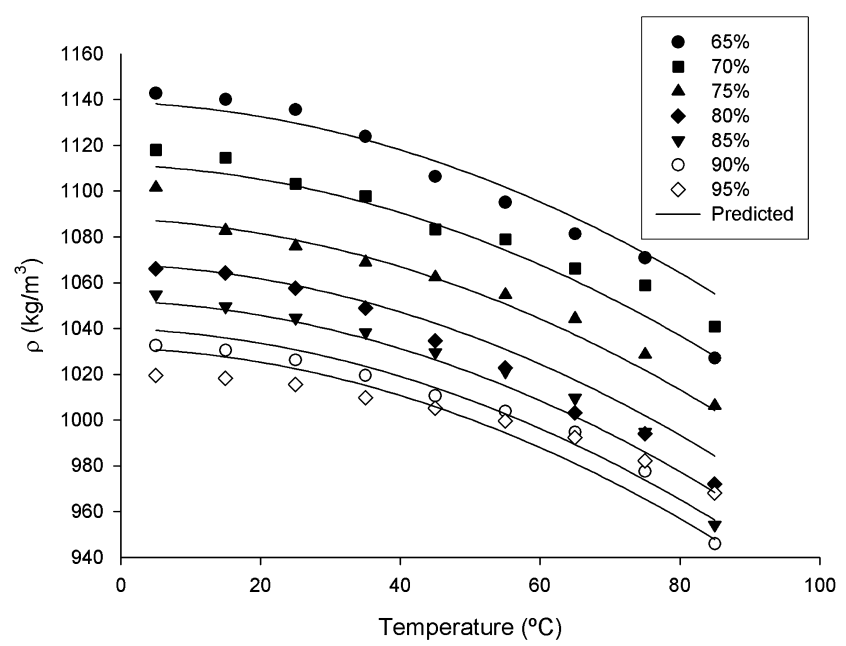

FIG. 1. EFFECTS OF TEMPERATURE AND MOISTURE CONTENT ON DENSITY OF JACKFRUIT PULP

because of the thermal expansion of a solution composed of several components. According to Constenla et al. (1989), solid concentration of mixtures directly affects this property.

The experimental values of density presented a very strong dependence on moisture content, but they were less affected by temperature. Ramos and Ibarz (1998), studying density of peach and orange juices with concentrations ranged at $10-60^{\circ}$ Brix, found experimental values near to values obtained at this work and also verifying a quadratic relationship with the concentration. Similar results were still obtained from other authors studying different fruits and their products, such as Japanese crabapple (Malus floribunda) juice (Cepeda and Villarán 1999) and apple juice (Constenla et al. 1989).

Specific Heat. In agreement with obtained experimental values, the specific heat varied from 2.70 to $3.92 \mathrm{~kJ} / \mathrm{kgC}$, as moisture content increased. Measurements of $c_{\mathrm{p}}$ of jackfruit pulp were not found in the literature. However, Telis-Romero et al. (1998) observed a similar behavior to specific heat of concentrated orange juice (34-73\% of total solids), and the obtained values fall into the range reported for other fruits and their products, like juices and pulps (Choi and Okos 1986; Constenla et al. 1989; Zainal et al. 2000; Shamsudin et al. 2005).

The relationship between specific heat and moisture content can be presented as a straight line where the specific heat increased as moisture tenor increased (Fig. 2). The relationship can be expressed as shown in Eq. (6): 


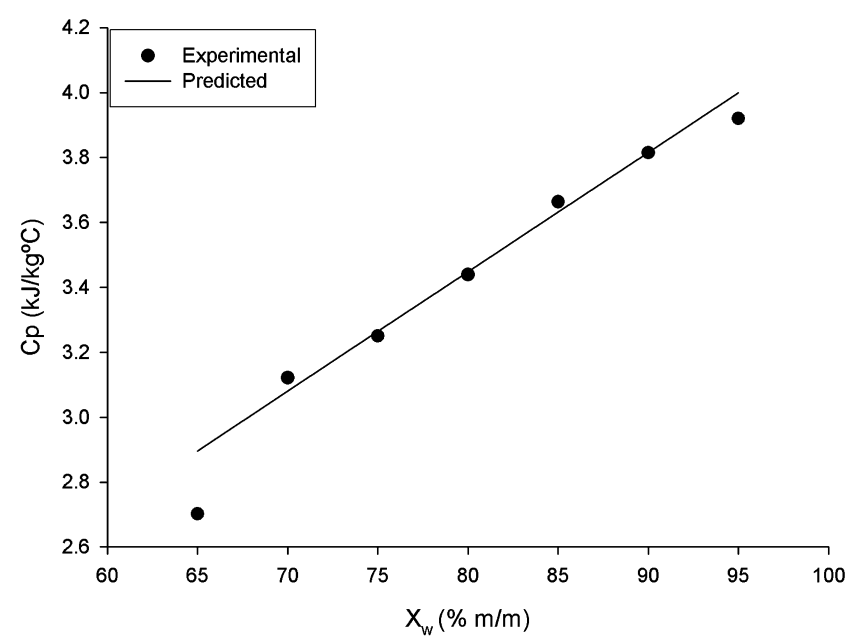

FIG. 2. EFFECTS OF MOISTURE CONTENT ON SPECIFIC HEAT OF JACKFRUIT PULP

$$
c_{\mathrm{p}}=0.505+0.038 X_{\mathrm{w}} \quad R^{2}=0.94
$$

From the results, one can conclude that as moisture content increased, better becomes the prediction. As higher the value of moisture content, more $c_{\mathrm{p}}$ values approximated to the constant water $c_{\mathrm{p}}$ value. The effect of total solids is less important because the various components (fat, protein, sugars and ashes) exert minor influence if compared to water, because of its high concentration.

Thermal Diffusivity and Thermal Conductivity. The relationship between thermal diffusivity and thermal conductivity with moisture content and temperature was obtained by multiple linear regression. It can be expressed by Eqs. (11) and (12), respectively.

$$
\begin{aligned}
\alpha= & 0.792 \times 10^{-8}-0.732 \times 10^{-8} T+0.591 \times 10^{-10} T^{2} \quad R^{2}=0.93 \\
& +0.273 \times 10^{-8} X_{\mathrm{w}}+0.477 \times 10^{-10} \mathrm{TX}_{\mathrm{w}} \\
& \\
k= & -1.050-0.117 \times 10^{-1} T+0.202 \times 10^{-3} T^{2} \quad R^{2}=0.90 \\
& +0.232 \times 10^{-1} X_{\mathrm{w}}
\end{aligned}
$$

Experimental results of thermal diffusivity $(\alpha)$, calculated results of thermal conductivity $(k)$ and the values obtained by the proposed models 


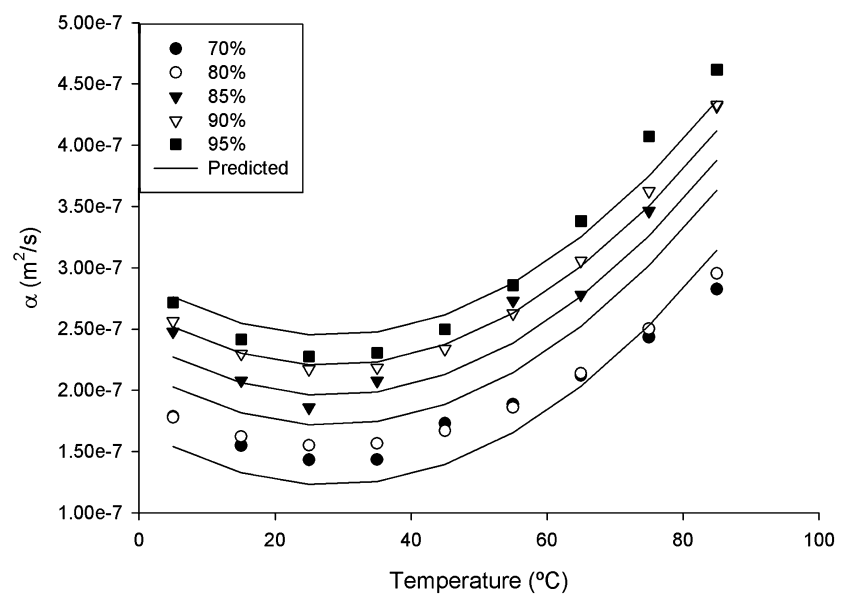

FIG. 3. EFFECTS OF TEMPERATURE AND MOISTURE CONTENT ON THERMAL DIFFUSIVITY OF JACKFRUIT PULP

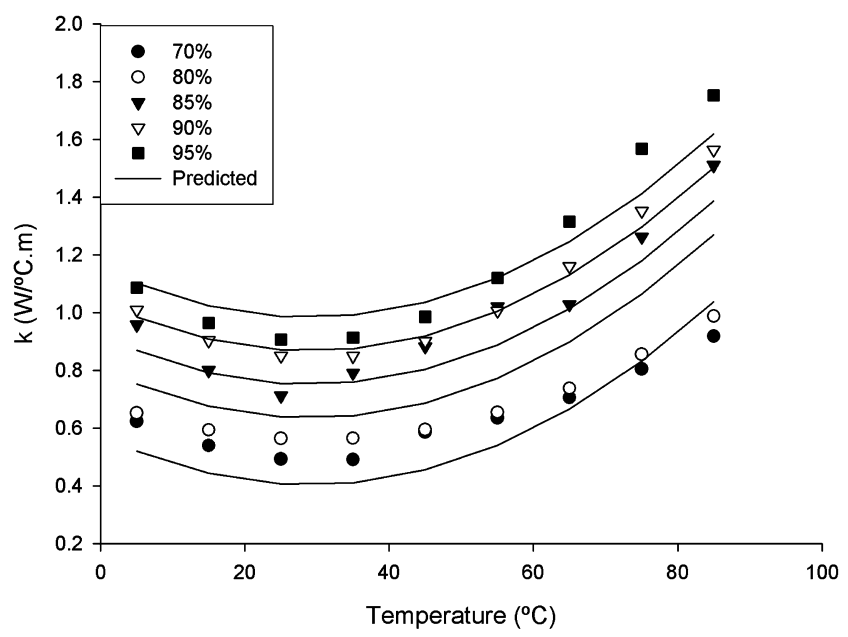

FIG. 4. EFFECTS OF TEMPERATURE AND MOISTURE CONTENT ON THERMAL CONDUCTIVITY OF JACKFRUIT PULP

(Eqs. 7 and 8) at the selected temperature levels ranging from 5 to $85 \mathrm{C}$ for the moisture content are shown in Figs. 3 and 4, respectively. These properties heavily depended of moisture content values. According to Azoubel et al. (2005), as water fraction of fruit juices increased, the thermal properties of 
fruit juices increased because if compared with thermal conductivity and thermal diffusivity of the solids present in the juice, the values of these properties for pure water are higher.

Telis-Romero et al. (1998), studying the effects of temperature and concentration on thermal diffusivity and thermal conductivity of concentrated orange juice (34-73\% of solids), verifying an increase on both properties with the reduction of solid content an elevation of temperature. Similar behavior was observed by Azoubel et al. (2005) studying cashew juice with soluble solid content at $5-25^{\circ}$ Brix. Zainal et al. (2000) verified that thermal conductivity of pink guava juice decreases with an elevation of solids content. The same behavior was observed at this work when the results were compared with these authors.

\section{CONCLUSION}

Jackfruit pulp is rich in carbohydrates and ashes, which is a potential source of energy and minerals to human nutrition. Its processing is essential to improve its consumption, mainly in urban centers. Moisture content and temperature under studied ranges affected significantly the thermophysical properties (i.e., density, thermal conductivity, specific heat and thermal diffusivity) of jackfruit pulp. Density decreased as temperature and moisture content increased. Thermal diffusivity and thermal conductivity were positively affected by an increase of moisture content and temperature above 30C, while specific heat increased as moisture content increased. Simple models were fitted, explaining adequately the studied properties.

\section{NOMENCLATURE}

A

$c_{\mathrm{p}}$

$c_{\mathrm{w}}$

$C_{\text {cal }}$

$k$

$m_{\mathrm{h}}$

$m_{\mathrm{c}}$

$m_{\mathrm{v}}$

$m_{\mathrm{s}}$

$m_{\mathrm{w}}$

$R$

$T$

rate to increase temperature $(\mathrm{C} / \mathrm{s})$

specific heat $(\mathrm{J} / \mathrm{kg} / \mathrm{C})$

specific heat of water $(\mathrm{J} / \mathrm{kg} / \mathrm{C})$

heat capacity of calorimeter $(\mathrm{J} / \mathrm{C})$

thermal conductivity $(\mathrm{W} / \mathrm{m} / \mathrm{C})$

mass of hot water

mass of cold water

pycnometer mass $(\mathrm{kg})$

sample mass $(\mathrm{kg})$

mass of water $(\mathrm{kg})$

internal radius of the capsule $(\mathrm{m})$

temperature $(\mathrm{C})$ 


$\begin{array}{ll}T_{\mathrm{c}} & \text { calorimeter + cold water temperature }(\mathrm{C}) \\ T_{\mathrm{h}} & \text { hot water temperature }(\mathrm{C}) \\ T_{0} & \text { calorimeter + initial temperature of water }(\mathrm{C}) \\ T_{\mathrm{e}} & \text { external temperature of the capsule }(\mathrm{C}) \\ T_{\mathrm{i}} & \text { internal temperature of the capsule }(\mathrm{C}) \\ T_{\mathrm{s}} & \text { initial temperature of the sample }(\mathrm{C}) \\ T_{\mathrm{eq}} & \text { equilibrium temperature }(\mathrm{C}) \\ X_{\mathrm{w}} & \text { water mass fraction (dimensionless) }\end{array}$

\section{Greek letters}

$\begin{array}{ll}\alpha & \text { thermal diffusivity }\left(\mathrm{m}^{2} / \mathrm{s}\right) \\ \rho & \text { density }\left(\mathrm{kg} / \mathrm{m}^{3}\right) \\ \rho_{\mathrm{w}} & \text { density of water }\left(\mathrm{kg} / \mathrm{m}^{3}\right)\end{array}$

\section{ACKNOWLEDGMENTS}

Thanks to Fundação de Amparo à Pesquisa do Estado da Bahia and Conselho Nacional de Desenvolvimento Científico e Tecnológico for financial support.

\section{REFERENCES}

AGUADO, M.A. and IBARZ, A. 1988. Variación de la densidad de un zumo de manzana con la temperatura y concentratión. Aliment., Aliment. Equip. Tecnol. 2, 209-216.

AOAC (ASSOCIATION OF OFFICIAL ANALYTICAL CHEMISTS). 1996. AOAC International, Official Methods of Analysis, 16th Ed., AOAC, Gaithersburg, MD.

AZOUBEL, P.M., CIPRIANI, D.C., EL-AOUAR, A.A., ANTONIO, G.C. and MURR, F.E.X. 2005. Effect of concentration on the physical properties of cashew juice. J. Food Eng. 66, 413-417.

BECKER, B.R. and FRICKE, B.A. 1999. Food thermophysical property models. Int. Commun. Heat Mass Transfer 26(5), 627-636.

BELIBAGLI, K.B., SPEERS, R.A. and PAULSON, A.T. 2003. Thermophysical properties of silver hake and mackerel surimi at cooking temperatures. J. Food Eng. 60, 439-448.

CEPEDA, E. and VILLARÁN, M.C. 1999. Density and viscosity of Malus floribunda juice as a function of concentration and temperature. J. Food Eng. 41, 103-107. 
CHOI, Y. and OKOS, M.R. 1986. Effects of temperature and composition on the thermal properties of foods. In Food Engineering and Process Applications: Transport Phenomena, Vol. 1 (M. Lemauguer and M. Jelen, eds.) pp. 93-101, Elsevier Applied Science Publishers, London, UK.

COIMBRA, J.S.R., GABAS, A.L., MINIM, L.A., GARCIA ROJAS, E.E., TELIS, V.R.N. and TELIS-ROMERO, J.T. 2006. Density, heat capacity and thermal conductivity of liquid egg products. J. Food Eng. 74, 186190.

CONSTENLA, D.T., LOZANO, J.E. and CRAPISTE, G.H. 1989. Thermophysical properties of clarified apple juice as a function of concentration and temperature. J. Food Sci. 54(3), 663-668.

DICKERSON, R.W., JR. 1965. An apparatus for the measurement of thermal diffusivity of foods. Food Technol. 19(5), 198-204.

FONTAN, R.C.I., SANTOS, L.S., BONOMO, R.C.F., LEMOS, A.R., RIBEIRO, R.P. and VELOSO, C.M. Thermophysical properties of coconut water affected by temperature. J. Food Process Eng. (in press) DOI:10.1111/j.1745-4530.2007.00222.x.

HWANG, M.P. and HAYAKAWA, K. 1979. A specific heat calorimeter for foods. J. Food Sci. 44(2), 435-448.

JAGADEESH, S., REDDY, L.B.S., SWAMY, G.S.K., GORB, K. and RAGHAVAN, G.S.V. 2007. Chemical composition of jackfruit (Artocarpus heterophyllus) selections of Western Ghats of India. Food Chem. 102, 361-365.

MAGERRAMOV, M.A., ABDULAGATOV, A.I., AZIZOV, N.D. and ABDULAGATOV, I.M. 2007. Effect of temperature, concentration, and pressure on the viscosity of pomegranate and pear juice concentrates. J. Food Eng. 80, 476-489.

MARCOTTE, M., TAHERIAN, A.R. and KARIMI, Y. 2008. Thermophysical properties of processed meat and poultry products. J. Food Eng. 88, 315-322.

MUNIZ, M.B., QUEIROZ, A.J.M., FIGUEIREDO, R.M.F. and DUARTE, M.E.M. 2006. Caracterização termofísica de polpas de bacuri. Ciênc. Technol. Aliment. 26(2), 360-368.

OMOBUWAJO, T.O., SANNI, L.A. and OLAJIDE, J.O. 2000. Physical properties of ackee apple (Blighia sapida) seeds. J. Food Eng. 45, 43-48.

OYELADE, O.J., ODUGBENRO, P.O., ABIOYE, A.O. and RAJI, N.L. 2005. Some physical properties of African star apple (Chrysophyllum alibidum) seeds. J. Food Eng. 67, 435-440.

RAHMAN, M.A., NAHAR, N., JABBAR, M.A. and MOSIHUZZAMAN, M. 1999. Variation of carbohydrate composition of two forms of fruit from jack tree (Artocarpus heterophyllus) with maturity and climatic conditions. Food Chem. 65, 91-97. 
RAMOS, A.M. and IBARZ, A. 1998. Density of juice and fruit puree as a function of soluble solids content and temperature. J. Food Eng. 35, 57-63.

RAPUSAS, R.S. and DRISCOLL, R.H. 1995. Thermophysical properties of fresh and dried white onion slices. J. Food Eng. 24, 149-164.

RAZAVI, S.M.A. and TAGHIZADEH, M. 2007. The specific heat of pistachio nuts as affected by moisture content, temperature, and variety. J. Food Eng. 79, 158-167.

RIBEIRO JÚNIOR, J.I. 2001. Análises Estatísticas no SAEG, pp. 169-226, UFV, Viçosa, Brazil.

SHAMSUDIN, R., MOHAMED, I.O. and YAMAN, N.K.M. 2005. Thermophysical properties of Thai seedless guava juice as affected by temperature and concentration. J. Food Eng. 66, 395-399.

SZCZESNIAK, A.S. 1983. Physical properties of foods: What they are and their relation to other food properties. In Physical Properties of Foods (M. Peleg and E.B. Bagley, eds.) pp. 1-4, AVI Publ. Co., Westport, CT. TANSAKUL, A. and CHAISAWANG, P. 2006. Thermophysical properties of coconut milk. J. Food Eng. 73, 276-280.

TELIS-ROMERO, J., TELIS, V.R.N., GABAS, A.L. and YAMASHITA, F. 1998. Thermophysical properties of Brazilian orange juice as affected by temperature and water content. J. Food Eng. 38, 27-40.

ZAINAL, B.S., ABDUL RAHMAN, R., ARIFF, A.B., SAARI, B.N. and ASBI, B.A. 2000. Effects of temperature on the physical properties of pink guava juice at two diffrent concentrations. J. Food Eng. 43, 55-59.

ZURITZ, C.A., MUÑOZ PUNTES, E., MATHEY, H.H., PÉREZ, E.H., GASCÓN, A., RUBIO, L.A., CARULLO, C.A., CHERNIKOFF, R.E. and CABEZA, M.S. 2005. Density, viscosity and coefficient of thermal expansion of clear grape juice at different soluble solid concentrations and temperatures. J. Food Eng. 71, 143-149. 